Journal of Agricultural Sciences
(Tarim Bilimleri Dergisi)

\title{
Effect of Preharvest Calcium Chloride Treatment on Some Quality Characteristics and Bioactive Compounds of Sweet Cherry Cultivars
}

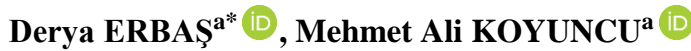

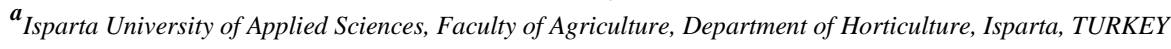 \\ ARTICLE INFO \\ Research Article \\ Corresponding Author: Derya ERBAŞ, E-mail: deryabyndr@gmail.com \\ Received: 04 February 2021 / Revised: 05 October 2021 / Accepted: 5 October 2021 / Online: 01 September 2022 \\ Cite this article \\ ERBAŞ D, KOYUNCU M A (2022). Effect of Preharvest Calcium Chloride Treatment on Some Quality Characteristics and Bioactive Compounds of Sweet Cherry Cultivars. Journal \\ of Agricultural Sciences (Tarim Bilimleri Dergisi), 28(3):481-489. DOI: 10.15832/ankutbd.874567
}

\section{ABSTRACT}

The effects of preharvest calcium chloride $\left(\mathrm{CaCl}_{2}\right)$ treatment on some quality characteristics and bioactive compounds of sweet cherry fruit (Prunus avium L. cvs. 0900 Ziraat, Sweetheart and Merton Late) were investigated. The $\mathrm{CaCl}_{2}(1 \%)$ solution was sprayed to the cherry trees at 21 and 35 days after full bloom stage. The trees served as control were treated with distilled water at the same days. $\mathrm{CaCl}_{2}$ treatment remarkably suppressed the respiration rate and increased titratable acidity and fruit firmness of cherries. Treated fruit had more attractive skin colour with higher $h^{\circ}$ and $L^{*}$ values compared to control. The individual soluble sugars and total sugar contents of $\mathrm{CaCl}_{2}$ treated cherries were lower than those of control fruit. The accumulation of ascorbic acid, stem chlorophyll, total phenolics and anthocyanin contents of fruit were delayed by $\mathrm{CaCl}_{2}$ treatment in all varieties. The antioxidant activities of all treated varieties were lower than those of control fruit. Based on these results, it can be set forth that preharvest $\mathrm{CaCl}_{2}$ treatment suppressed ripening processes including respiration rate and maintained firmness and titratable acidity of cherries by maintaining cell integrity in all varieties during the fruit development period.

Keywords: Antioxidant activity, Ascorbic acid, Firmness, Fruit sugars, Total phenolic content, Prunus avium L

\section{Introduction}

In recent years, sweet cherry (Prunus avium L.) has become one of the most attractive fruit for producers in the world because of its increasing economic value (Winkler \& Knoche 2019). It has also gained popularity for consumers due to its organoleptic and nutritional characteristics. Cherries are rich in nutrients such as vitamin $\mathrm{C}, \mathrm{A}$ and $\mathrm{K}$, magnesium, potassium and some other minerals. In addition, sweet cherry contains bioactive compounds with antioxidant characteristics (Ozturk et al. 2019), which have positive effects on human health (Ballistreri et al. 2013). Sweet cherry is generally consumed as fresh; therefore, the improved quality characteristics that affect consumer acceptability are mostly important. The outstanding quality characteristics of sweet cherry are fruit firmness, fruit skin and stem color, acidity and sugar content, which influence consumer acceptance. Especially the fruit firmness, affected by preharvest calcium $(\mathrm{Ca})$ treatments, is indispensable for quality evaluation and reaching overseas markets (Romano et al. 2006; Göksel 2011). Additionally, preharvest Ca treatments can reduce cracking rate which causes significant economic loss and reduces fruit quality at harvest time (Erogul 2014). The harvested sweet cherry fruit are susceptible to handling, transportation and storage due to perishability and high respiration rate (Mozetič et al. 2006; Romano et al. 2006). The main causes of quality losses during marketing chain are water losses, softening, color deterioration and stem browning (Martínez-Romero et al. 2006). Therefore, all preharvest treatments, which increase flesh firmness and suppress ripening and senescence processes including respiration, to improve postharvest quality of sweet cherries are very crucial. Dong et al. (2019) reported that strategies to increase fruit firmness are essential to obtain high quality sweet cherries for high-value export markets.

$\mathrm{Ca}$ affects the cell wall structure via cross-linking of pectins, regulates the membrane permeability of tissues and plays an important role in cellular signalling responses in fruit (Kirkby \& Pilbeam 1984; Tsantili et al. 2007). Sweet cherries that contain insufficient $\mathrm{Ca}$ are susceptible to some quality losses related to fruit firmness (Dong et al. 2019). It is known that, preharvest Ca treatments directly improve fruit quality, especially flesh firmness, of sweet cherries (Tsantili et al. 2007). Furthermore, it was reported that $\mathrm{Ca}$ applications extended postharvest life and delayed quality losses of sweet cherries by suppressing respiration rate and increasing tissue strength of fruit (Vangdal et al. 2008; Wang et al. 2014). However, these studies revealed different results depending on the source of $\mathrm{Ca}$, sweet cherry cultivars, treatment time and dose (Correia et al. 2019). Similarly, Tsantili et al. (2007) and Winkler \& Knoche (2019) have reported that, interestingly, little is known about the detailed effect of preharvest $\mathrm{Ca}$ treatments on sweet cherry quality at harvest. These authors also indicated that Ca treatments 
gave beneficial and clear results in some studies, while there was no significant effect in others. On the other hand, although Ca treatments have positive effects on fruit quality, it has been stated that inorganic salts sometimes cause bitter and salty taste, especially in high dose (Monsalve-Gonalez et al. 1993). Likewise, Wang et al. (2014) found an increased stem browning in sweet cherries treated with higher dose than $1 \%$. These findings reveal that detailed information about the effects of preharvest $\mathrm{Ca}$ treatments on the quality of sweet cherries is urgently needed. Therefore, this study aimed to determine the effects of preharvest $\mathrm{CaCl}_{2}$ treatment on some quality characteristics and bioactive compounds of sweet cherry at harvest time.

\section{Material and Methods}

\subsection{Plant material}

0900 Ziraat, Sweetheart and Merton Late sweet cherry (Prunus avium) varieties, 16 years old and grafted on Prunus avium L. rootstocks, were used for preharvest $\mathrm{CaCl}_{2}$ treatment in 2019. The $\mathrm{CaCl}_{2}$ [(1\%), Merck, Germany] solution containing Tween 20 [(0.1\%), Merck, Germany] was applied to the trees two times (three replicates- one tree for each) by using hand sprayer (Pomilsan, Turkey) at 21 and 35 days after full bloom (DAFB) stage. The application dose (1\%) was determined based on previous studies (Tsantili et al. 2007; Vangdal et al. 2008; Wang et al. 2014). Control trees were sprayed with distilled water $(0.1 \%$ Tween 20$)$ at the same days (21 and 35 DAFB). Fruit were hand-harvested at optimum stage based on fruit skin color and maturity index (SSC/TA) from the research orchard of the Isparta, Turkey. The sweet cherry trees were planted at $4 \times 3 \mathrm{~m}$ spacing and trained by Goble pruning system. Cultural practices (fertilization, disease control and irrigation) of orchard were regularly applied. Immediately after harvest, sweet cherry fruit were transported (within half-hour) to the laboratory, and foreign parts and injured fruit were removed. The following analyses were performed as three replicates using randomly selected fruit samples.

\subsection{Fruit firmness $(F F)$}

Fifteen sweet cherry fruit from each replicate were used for firmness evaluation. The firmness of sweet cherries was measured by a texture analyzer machine (LF Plus-Lloyd Instruments) with a $50 \mathrm{~N}$ load cell (5 mm cylindrical probe). The results were expressed as Newton $(\mathrm{N})$.

\subsection{Soluble solids content (SSC) and titratable acidity (TA)}

The SSC of sweet cherries was determined using a digital refractometer (Atago-Pal 1). For TA, fruit juice (10 mL) was titrated using sodium hydroxide $(0.1 \mathrm{~N})$ up to $\mathrm{pH} 8.1$. The results were expressed as the equivalent percentage $(\%)$ of malic acid (Erbas et al. 2018)

\subsection{Fruit skin color}

Skin color of sweet cherries (20 fruit for each replicate) was determined using colorimeter (Minolta CR-300). The L*, a* and $\mathrm{b}^{*}$ values, used to determine a three-dimensional color space, were measured, and then the chroma $\left[\mathrm{C}^{*}=\left(\mathrm{a}^{* 2}+\mathrm{b}^{* 2}\right)^{1 / 2}\right]$ and hue angle $\left(\mathrm{h}^{\circ}=\tan ^{-1} \mathrm{~b}^{*} / \mathrm{a}^{*}\right)$ were calculated using $\mathrm{a}^{*}$ and $\mathrm{b}^{*}$ values.

\subsection{Respiration rate $(R R)$}

Respiration rate of cherry fruit was measured by a gas chromatography. Fruit (140-150 g) were placed in a hermetically sealed glass jar $(1 \mathrm{~L})$ and kept at room condition. After $1 \mathrm{~h}$, gas sample was taken from glass jar using a gas-tight syringe, and injected into a gas chromatography (Agilent, $6890 \mathrm{~N}$ ). The thermal conductivity detector was used for the analysis of $\mathrm{CO}_{2}$. The RR was calculated based on $\mathrm{CO}_{2}$ released by fruit, and results were expressed as $\mathrm{mL} \mathrm{CO}_{2} \mathrm{~kg}^{-1} \mathrm{~h}^{-1}$ (Erbas et al. 2018).

\subsection{Stem chlorophyll content (SCC)}

Chlorophyll extraction and stem chlorophyll analysis were performed according to procedure described by Göksel (2011). The stem samples ( $3 \mathrm{~g}$ ) were placed in test tubes and added $50 \mathrm{~mL}$ acetone $(90 \%)$. The samples with acetone (Sigma, Aldrich) were kept at dark for overnight. After extraction, the absorbance of the samples was read at 663 and $645 \mathrm{~nm}$ using a spectrophotometer (Varian Cary Bio 100, Australia). The values were calculated as $\left[8.02 \times\left(\mathrm{A}_{663}\right)+20.2 \times\left(\mathrm{A}_{645}\right)\right]$, and results were expressed as $\mathrm{mg} 100 \mathrm{~g}^{-1}$.

\subsection{Ascorbic acid (AsA)}

Ascorbic acid analysis of sweet cherry fruit was performed by HPLC method recommended by Watada (1982). The $5 \mathrm{~mL}$ sweet cherry juice was placed in a test tube, and $5 \mathrm{~mL}$ metaphosphoric acid $\left(\mathrm{HPO}_{3}\right)$ solution $(6 \%)$ was added. The mixture was centrifuged at $4{ }^{\circ} \mathrm{C}$ for $10 \mathrm{~min}$, and then $0.5 \mathrm{~mL}$ of the clear portion of the centrifuge tube was added to $10 \mathrm{~mL}$ of $\mathrm{HPO}_{3}$ solution $(6 \%)$. This mixture was injected into the HPLC device after filtration with a PVDF (polyvinylidene fluoride) filter 
(Millipore, Bedford, Mass., USA) with a pore diameter of $0.45 \mu \mathrm{m}$. Ascorbic acid was identified by comparison with the arrival time of the peak in the chromatogram of the samples and the arrival time of the peak in the chromatogram of the ascorbic acid standard. [Column: ODS-3 C-18 column $(5 \mu \mathrm{m}, 250 \times 4.6$ i.d. $)$; Column temperature: $25^{\circ} \mathrm{C}$; Mobile phase: Potassium dihydrogen phosphate $\left(\mathrm{KH}_{2} \mathrm{PO}_{4}\right)$; Flow rate: $0.5 \mathrm{~mL} \mathrm{~min}^{-1}$; Injection amount: $10 \mu \mathrm{L}$; Wavelength: $210 \mathrm{~nm}$. The AsA content was expressed as $\mathrm{mg}$ in $100 \mathrm{~g}(\mathrm{FW})$.

\subsection{Extraction for total phenolic content (TPC) and antioxidant activity (AA)}

The sweet cherry sample $(5 \mathrm{~g})$ was placed in a tube $(50 \mathrm{~mL})$, and $5 \mathrm{~mL} 80 \%$ methanol (Sigma, Aldrich) was added. After homogenization with a homogenizer (IKA, Germany) samples were kept at dark condition $\left(4{ }^{\circ} \mathrm{C}\right)$ for $14-16 \mathrm{~h}$. The supernatants were stored in a deep freezer at $-20^{\circ} \mathrm{C}$ until the day of analysis (up to a week) (Thaipong et al. 2006).

\subsection{TPC and $A A$}

Total phenolic content of sweet cherries was determined using the Folin-Ciocalteu method as described by Thaipong et al. (2006). The standard curve was developed using gallic acid standard (Merck). The absorbance was read by a spectrophotometer (Varian Cary Bio 100, Australia) at $725 \mathrm{~nm}$. Results were calculated as mg of gallic acid equivalent (GAE) per $100 \mathrm{~g}^{-1} \mathrm{FW}$. The ferric reducing antioxidant power (FRAP) assay were used for evaluation of antioxidant capacity in sweet cherry fruit (Thaipong et al. 2006). The calibration curve was developed using Trolox standard (Sigma, Aldrich). The absorbance was read by a spectrophotometer (Varian Cary Bio 100, Australia) at $593 \mathrm{~nm}$. Results were calculated as Trolox equivalents (TE) in $\mathrm{mg} \mathrm{g}^{-1} \mathrm{FW}$.

\section{Total anthocyanin content (TAC)}

The $\mathrm{pH}$ differential method proposed by Ağlar et al. (2017) was used to determine the TAC. The extracted samples were combined with potassium chloride and sodium acetate buffers (pH 1.0 and 4.5, respectively) in a 1:20 ratio (v:v). After kept for $15 \mathrm{~min}$ (for equilibration period) the absorbances of solutions were measured using a spectrophotometer (Varian Cary Bio 100, Australia) at 533 and $700 \mathrm{~nm}$. A corrected absorbance value was calculated as $\left[\left(\mathrm{A}_{520}-\mathrm{A}_{700}\right) \mathrm{pH}{ }_{1.0}-\left(\mathrm{A}_{520}-\mathrm{A}_{700}\right) \mathrm{pH}{ }_{4.5}\right]$. The results were expressed as $\mathrm{mg}$ in kg cyanidin 3-glucoside (cy-3-glu) on FW basis (mg cy-3-glu kg FW).

\subsection{Sugars}

Sugar profile analysis of sweet cherries was performed by HPLC according to Melgarejo et al. (2000). Cherry samples were centrifuged at $20^{\circ} \mathrm{C}$ for $30 \mathrm{~min}$. After centrifugation, the clarified portion was filtered with PVDF filter $(0.45 \mu \mathrm{m}, \mathrm{Millipore}$, Bedford, Mass., USA) and injected to the HPLC. Glucose, fructose and sucrose solutions were analyzed in the same conditions, and the equations defining the curves were calculated by linear regression analysis. Using this equation, the amount of sugar in sweet cherry fruit was determined as $\mathrm{g} \mathrm{kg}^{-1}$. Each sugar is defined by comparison with the arrival time of the peak in the chromatogram of the samples and the arrival time of the peak in the standard chromatogram. The Shimadzu RID-10A model refractive index detector was used. Acetonitrile/water (70/30) was used as the mobile phase for separation of sugar components. The separation was performed isocratically with an Inertsil $\mathrm{NH}_{2}(5 \mu \mathrm{m}, 250 \times 4.6$ i.d.) column at a flow rate of 0.9 $\mathrm{mL} \min ^{-1}$. The volume of injection and the column temperature were $10 \mu \mathrm{L}$ and $25^{\circ} \mathrm{C}$, respectively.

\subsection{Statistical analysis}

The study was conducted using completely randomized factorial design with 3 replicates (each tree was considered as a replicate). The data were analyzed using Minitab 18 statistics software. The differences among means were compared with Tukey's range test $(5 \%)$.

\section{Results and Discussion}

\subsection{Fruit firmness}

Fruit firmness is, probably, one of the most important quality characteristics in sweet cherry for consumer acceptance. Preharvest $\mathrm{CaCl}_{2}$ treatment significantly increased fruit firmness in all varieties compared to control samples. At harvest, the firmness values of Ca treated cherries were 6.1 N (0900 Ziraat), 4.9 N (Sweetheart) and 3.9 N (Merton Late) whereas, control fruit had $5.8 \mathrm{~N}, 4.7 \mathrm{~N}$ and $3.3 \mathrm{~N}$ fruit firmness, respectively (Figure 1). Similarly, Winkler \& Knoche (2019) stated an improvement in the fruit firmness of sweet cherries by pre-and postharvest Ca applications. Moreover, Lidster et al. (1978) determined a highly-significant relationship $\left(\mathrm{r}^{2}=0.88\right)$ between the fruit firmness of sweet cherries and Ca content in fruit. This strong relationship can be explained by that $\mathrm{Ca}$ maintains the mechanical properties and integrity of the cell wall, and thus retards fruit softening (Saba \& Sogvar 2016). The membrane stabilization in fruit tissues is achieved by Ca ion, which bridges phosphate and carboxylate groups of phospholipids and proteins at membrane (Winkler et al. 2020). The findings of the 
present study are in agreement with the previous works on sweet cherries (Tsantili et al. 2007; Dong et al. 2019) in which preharvest $\mathrm{Ca}$ treatments remarkably increased fruit firmness.

\subsection{Soluble solids content and titratable acidity}

The SSC, which represents soluble sugars, was decreased by Ca treatment compared to control regardless of variety, varying between 11.8\% (0900 Ziraat) and 16.3\% (Sweetheart) at harvest. Control fruit had 24.6\% (0900 Ziraat), 17.9\% (Sweetheart) and $1.7 \%$ (Merton Late) higher SSC than those of Ca treated cherries. These results can be attributed to the suppressed ripening processes, which result in decreased respiration rate (Figure 1), in Ca-treated cherry fruit depending on cell integrity and suppressed metabolic processes. Diaz-Mula et al. (2017) reported that Ca treatment retarded the increase of SSC in sweet cherries by slowing down the metabolic activities via stabilization of the cell wall and inhibiting the activity of cell wall degradation enzymes. In sweet cherry, TA is very important quality parameter for consumer preference, because the flavor loss of cherries is mainly associated with organic acid degradation. Although, there was no statistically difference between treated and control samples, $\mathrm{Ca}$ treated fruit exhibited relatively higher TA content in all varieties in relation to slowed ripening processes. Ca treated cherries had 2.7\% (0900 Ziraat), 5.1\% (Sweetheart) and 8.7\% (Merton Late) higher TA than those of control samples (Figure 1). In accordance with the present study, Tsantili et al. (2007) reported that preharvest Ca treatments maintained TA content of sweet cherries compared to control at harvest. The delay in acidity loss during fruit growing period can be explained by the suppressing effect of $\mathrm{Ca}$ on fruit metabolic activity, including ripening processes and respiration rate (Figure 1). It is well known that organic acids are a major component of respiration processes, and the use of organic acids as substrates in these reactions reduces acid content in fruit.

\subsection{Respiration rate $(R R)$}

The effect of Ca treatment on the RR of sweet cherries was statistically significant. The RR, an indicator of metabolic activity and ripening processes, was remarkably decreased by $\mathrm{Ca}$ treatment in all varieties at harvest. The lowest RR was obtained from the $\mathrm{Ca}$ treated fruit of 0900 Ziraat $\left(3.2 \mathrm{mLCO}_{2} \mathrm{~kg}^{-1} \mathrm{~h}^{-1}\right)$ followed by Merton Late $\left(4.4 \mathrm{mLCO}_{2} \mathrm{~kg}^{-1} \mathrm{~h}^{-1}\right)$ and $\mathrm{Sweetheart}(7.6$ $\mathrm{mLCO}_{2} \mathrm{~kg}^{-1} \mathrm{~h}^{-1}$ ), and these values were $4.7 \mathrm{mLCO}_{2} \mathrm{~kg}^{-1} \mathrm{~h}^{-1}, 5.2 \mathrm{mLCO}_{2} \mathrm{~kg}^{-1} \mathrm{~h}^{-1}$ and $8.0 \mathrm{mLCO}_{2} \mathrm{~kg}^{-1} \mathrm{~h}^{-1}$, respectively in control samples (Figure 1). These findings revealed that preharvest Ca treatment suppressed the RR of cherries by delaying senescence processes compared to control fruit. Likewise, the decrease in SSC and total sugars, and the increase in TA and fruit firmness by $\mathrm{Ca}$ treatment during fruit maturation (Figure 1 and Figure 3 ) are also indicators of delayed senescence. Kirkby \& Pilbeam (1984) have reported that senescence is related to some processes such as the breakdown in the compartmentation of the cell and the increase in respiration rate after the leakage of respiratory substrates from the vacuole to the cytoplasm containing respiratory enzymes. The monosaccharides produced by dissolving of cell wall pectin and hemicellulose are used as respiratory substrates (Ranjbar et al. 2018). These metabolic processes are closely related to cell wall integrity and tissue strength, which might be achieved by Ca treatments in fruit. Similarly, it has been speculated that the typical signs of senescence in fruit during maturation are similar to those of Ca deficiency and can be delayed by Ca treatment (Kirkby \& Pilbeam 1984).
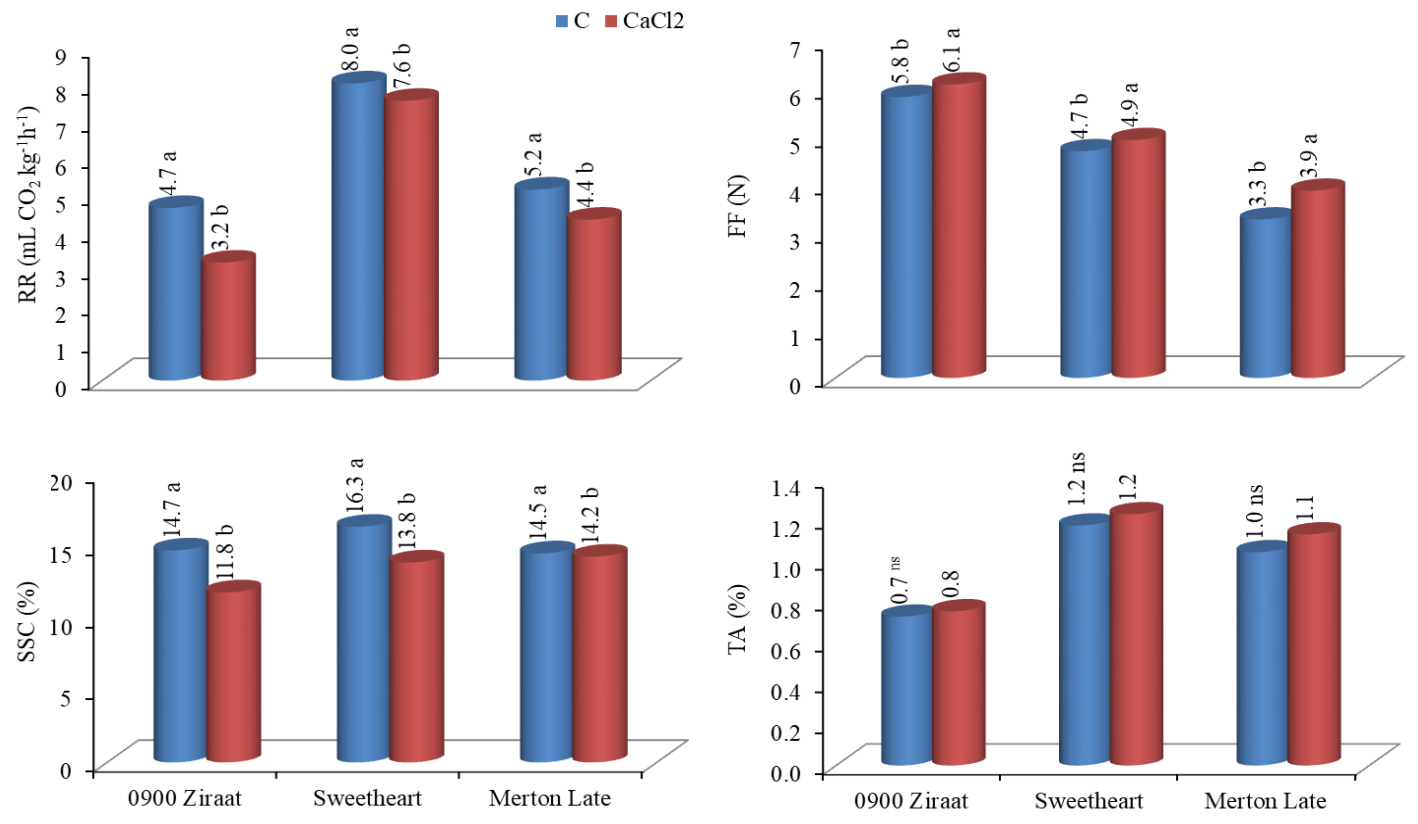

Figure 1- The effect of preharvest $\mathrm{CaCl}_{2}$ treatment on RR, FF, SSC and TA of different sweet cherry varieties. RR:

Respiration rate, FF: Fruit firmness, SSC: Soluble solids content, TA: Titratable acidity, C: Control, CaCl2: Calcium chloride, ns: represents non-significance $P<0.05$. Statistical comparisons were made within each cultivar. Means followed by different letters are statistically significant at $\mathbf{P}<0.05$ 


\subsection{Fruit skin color}

The effect of treatment on $\mathrm{L}^{*}$ and $\mathrm{h}^{\circ}$ values was significant except for Sweetheart variety but $\mathrm{C}^{*}$ value was not affected by preharvest $\mathrm{CaCl}_{2}$ treatment (Figure 2). Crisosto et al. (2003) reported that the consumer acceptance of sweet cherries was associated with mainly skin color, which changes depending on pre-and postharvest applications. The chromatic functions of $\mathrm{L}^{*}, \mathrm{C}^{*}$ and $\mathrm{h}^{\circ}$ correlate closely with the change of color and anthocyanin accumulation in sweet cherries during maturation (Mozetic et al. 2004; Gonçalves et al. 2007). In the present study, control fruit had less attractive skin color, which are correlated with the reduction of $\mathrm{h}^{\circ}$ and $\mathrm{L}^{*}$ values. The Ca treated cherries showed higher $\mathrm{L}^{*}$ and $\mathrm{h}^{\circ}$ values compared to control fruit in all varieties at harvest. The highest $L^{*}(47.2)$ and $h^{\circ}(37.8)$ values were obtained from the Ca treated fruit of 0900 Ziraat variety. Mozetic et al. (2004) indicated that the accumulation of anthocyanins in sweet cherries during ripening resulted in a decrease in color intensity and redness as described by $\mathrm{L}^{*}, \mathrm{C}^{*}$ and $\mathrm{h}^{\circ}$ values. Moreover, a negative correlation was found between anthocyanin content and $\mathrm{L}^{*}$ and $\mathrm{h}^{\circ}$ values of sweet cherries during maturation (Gonçalves et al. 2007). Based on these findings, it can be speculated that suppressed ripening and respiration processes by $\mathrm{CaCl}_{2}$, in the present study, resulted in higher color values such as $\mathrm{L}^{*}$ and $\mathrm{h}^{\circ}$. In accordance with this thought, Gonçalves et al. (2007) reported that the $\mathrm{L}^{*}$ and $\mathrm{h}^{\circ}$ values of the ripe sweet cherries were always lower than those of partially ripe fruit.

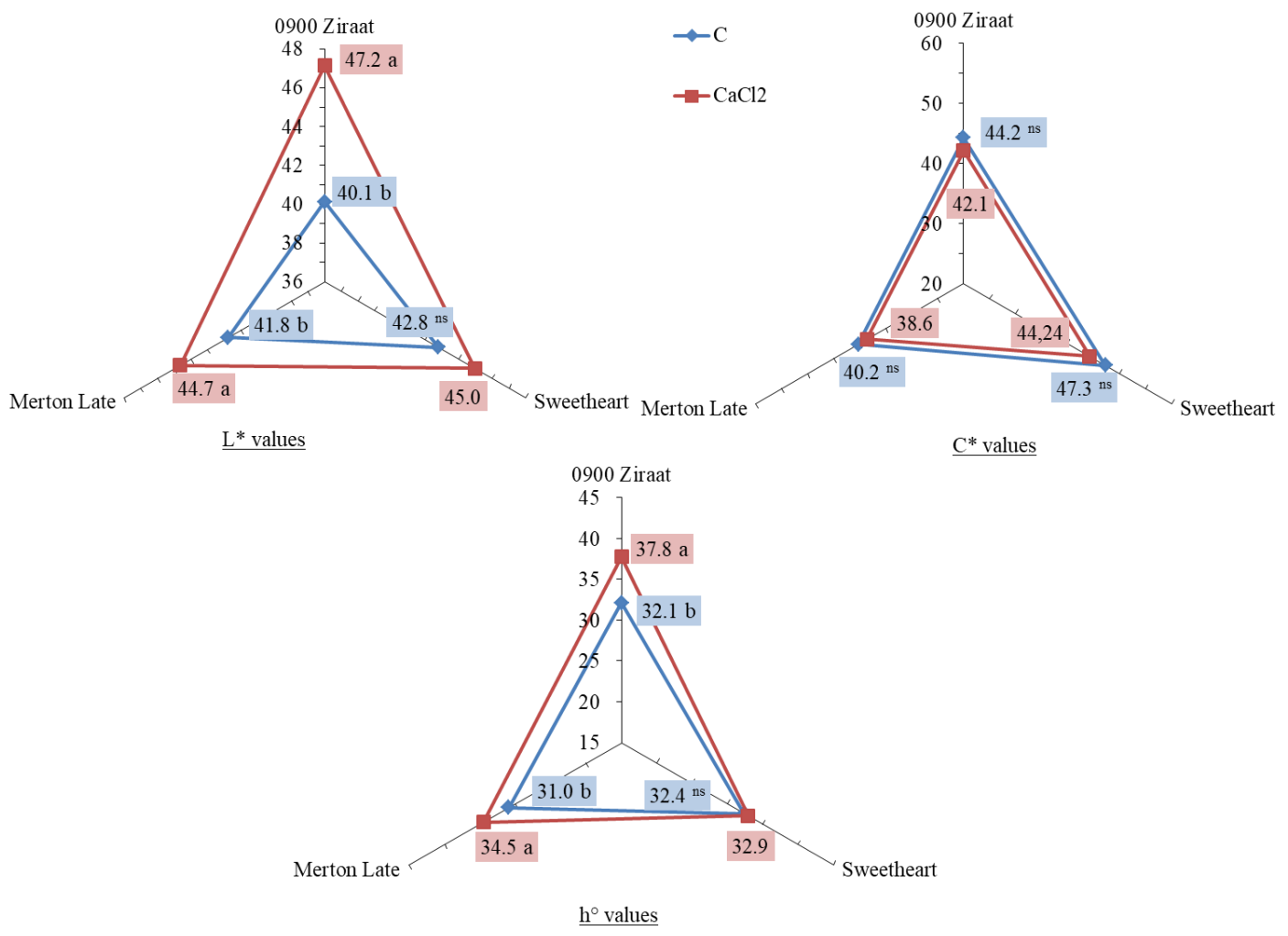

Figure 2- The effect of preharvest $\mathrm{CaCl}_{2}$ treatment on fruit skin color $\left(\mathrm{L}^{*}, \mathrm{C}^{*}\right.$ and $\left.\mathrm{h}^{\circ}\right)$ of different sweet cherry varieties. $\mathrm{C}$ :

Control, $\mathrm{CaCl}_{2}$ : Calcium chloride, $\mathrm{C}^{*}$ : Chroma, $\mathrm{h}^{\circ}$ : Hue angle, ns: represents non-significance $\mathbf{P}<0.05$. Statistical comparisons were made within each cultivar. Means followed by different letters are statistically significant at $P<0.05$.

\subsection{Sugars}

The $\mathrm{CaCl}_{2}$ treatment significantly influenced the glucose and sucrose contents of all varieties but the fructose was affected only in Merton Late variety. The glucose and fructose were the major soluble sugars followed by sucrose at harvest (Figure 3) as reported in previous studies carried out on sweet cherry (Serrano et al. 2005; Mahmood et al. 2012; Michailidis et al. 2017). Both individual soluble sugar (glucose, fructose, sucrose) and total sugar contents of $\mathrm{CaCl}_{2}$ treated cherries were lower than those of control fruit. However, the effect of $\mathrm{CaCl}_{2}$ treatments varied depending on varieties. For example, the control fruit of Merton Late had remarkable higher glucose $(11.8 \%)$ and fructose $(11.4 \%)$ content than those of Ca treated cherries, while these differentiations between treated and untreated samples were $0.5 \%$ and $1.0 \%$ in Sweetheart variety, respectively (Figure 3). It is known that different sweet cherry varieties exhibit various sugar profiles during maturation (Mahmood et al. 2012). The total sugar contents of control fruit were also higher 5.8\% (0900 Ziraat), 1.2\% (Sweetheart) and 1.6\% (Merton Late) than those treated with $\mathrm{CaCl}_{2}$ (Figure 3). The lower sugar content of Ca treated fruit in all varieties at harvest might be attributed to the suppressing effect of $\mathrm{CaCl}_{2}$ on fruit metabolic processes including ripening due to increased cell integrity and tissue strength. It is well known from previous studies that the soluble sugar (glucose, fructose and sucrose) concentration of cherry fruit increases as the fruit ripens (Romano et al. 2006; Mahmood et al. 2012). Moreover, Serrano et al. (2005) found a linear relationship $\left(\mathrm{R}^{2}=0.99\right)$ between the soluble sugar accumulation and ripening in sweet cherry fruit during fruit development 
period. On the other hand, Michailidis et al. (2017) reported that the strengthened cell wall in sweet cherries might reduce polygalacturonase activity by limiting the contact of enzyme with substrates. These results are consistent with the findings of our study that showed a higher fruit firmness and lower respiration rate in Ca treated fruit (Figure 1).
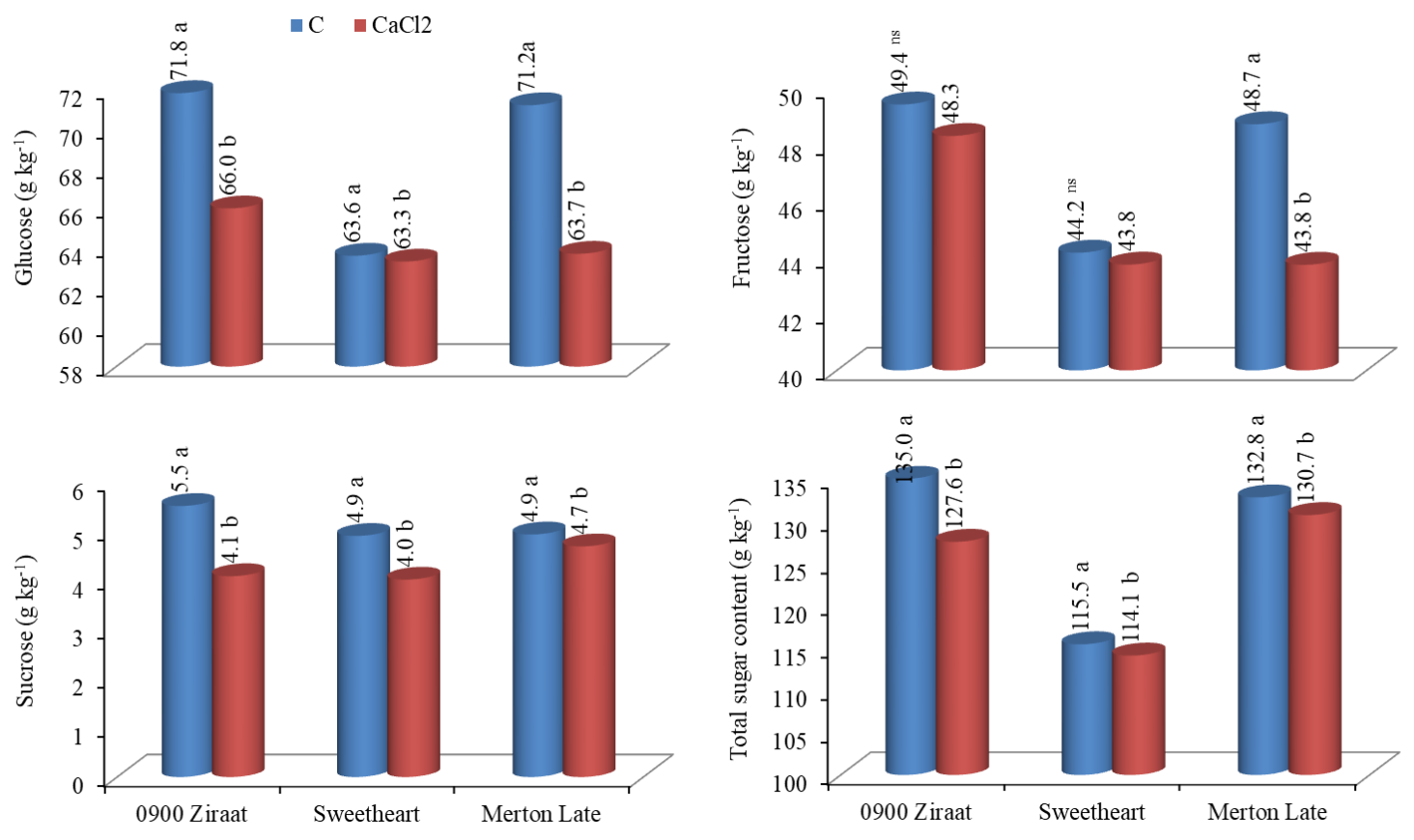

Figure 3- The effect of preharvest $\mathrm{CaCl}_{2}$ treatment on glucose, fructose, sucrose and total sugar content of different sweet cherry varieties. $\mathrm{C}$ : Control, $\mathrm{CaCl}_{2}$ : Calcium chloride, ns: represents non-significance $\mathbf{P}<0.05$. Statistical comparisons were made within each cultivar. Means followed by different letters are statistically significant at $P<0.05$.

\subsection{Stem chlorophyll content}

Consumers prefer green stem color, which is an indicator of the freshness in sweet cherry fruit (Schick \& Toivonen 2002). Stem color of sweet cherry fruit turns from green to brown because of the breakdown of chlorophyll during ripening processes. In the present study, the chlorophyll contents of $\mathrm{CaCl}_{2}$ treated cherry stems were $4.7 \%$ (0900 Ziraat), 11.3\% (Sweetheart) and $17.3 \%$ (Merton Late) higher than those of control fruit (Table 1). These results revealed that Ca treatments delayed chlorophyll degradation of stems, in agreement with of Wang et al. (2014) who reported that Ca treatments maintained the green color of cheery stems during senescence. The stem browning of cherries is a result of the reduced membrane integrity caused by damaged cells, which allows to mix polyphenol oxidase and polyphenol substance in cell (Wang et al. 2014). Similar to our findings, Göksel (2011) also noted a rapid decline in total chlorophyll content of cherry stems throughout ripening. The highest

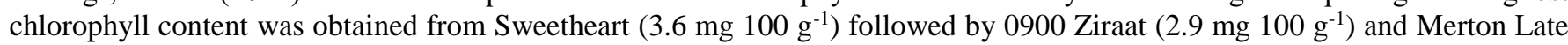
$\left(2.7 \mathrm{mg} 100 \mathrm{~g} \mathrm{~g}^{-1}\right.$ ) varieties at harvest (Table 1). These different results can be attributed to the variation in the response of each variety to $\mathrm{CaCl}_{2}$. This positive effect of $\mathrm{Ca}$ on chlorophyll degradation can also be explained by its reducing effect on the oxidation and senescence processes of fruit stems. Similarly, the delaying in stem browning (oxidation) of sweet cherries was attributed to the suppressed ripening and senescence processes by $\mathrm{CaCl}_{2}$ treatment (Tsantili et al. 2007).

\subsection{Ascorbic acid}

Ascorbic acid is considered a crucial nutritional component in fresh horticultural crops (Koyuncu et al. 2019). Preharvest $\mathrm{CaCl}_{2}$ treatment significantly decreased the AsA content of sweet cherries except for 0900 Ziraat variety. The AsA contents of fruit were determined as $10.1,12.6$ and $9.0 \mathrm{mg} 100 \mathrm{~g}^{-1}$ in 0900 Ziraat, Sweetheart and Merton Late varieties at harvest,

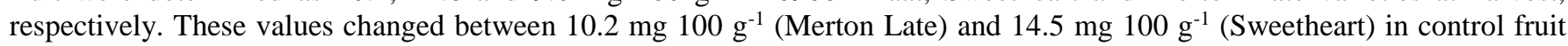
(Table 1). The decreasing of AsA content by preharvest Ca treatment can be attributed to the reduced ripening processes. It is known that preharvest Ca treatments retard fruit ripening (Tsantili et al. 2007), and thus the accumulation of AsA, during fruit development period (from full bloom to harvest) in sweet cherries. On the other hand, postharvest Ca treatments increased AsA content of Carnelion sweet cherry (Aghdam et al. 2013). These various results can be due to different variety, maturity stage and application doses and time. 
Table 1- The effect of preharvest $\mathrm{CaCl}_{2}$ treatment on TPC, AsA, TAC, AA and SSC of different sweet cherry varieties

\begin{tabular}{|c|c|c|c|c|c|c|}
\hline Cultivars & $T$ & $T P C$ & $A s A$ & $T A C$ & $A A$ & $S C C$ \\
\hline \multirow{3}{*}{0900 Ziraat } & $\mathrm{C}$ & $35.3 \mathrm{a}$ & 10.3 & $22.1 \mathrm{a}$ & 3.5 & 2.8 \\
\hline & $\mathrm{CaCl}_{2}$ & $34.5 \mathrm{~b}$ & 10.1 & $19.7 \mathrm{~b}$ & 3.4 & 2.9 \\
\hline & $P$ & $*$ & ns & $* *$ & ns & ns \\
\hline \multirow{3}{*}{ Sweatheart } & $\mathrm{C}$ & $49.9 \mathrm{a}$ & $14.5 \mathrm{a}$ & $27.5 \mathrm{a}$ & $3.3 \mathrm{a}$ & 3.2 \\
\hline & $\mathrm{CaCl}_{2}$ & $47.9 \mathrm{~b}$ & $12.6 \mathrm{~b}$ & $25.6 \mathrm{~b}$ & $3.2 \mathrm{~b}$ & 3.6 \\
\hline & $P$ & $*$ & $*$ & $*$ & $*$ & $\mathrm{~ns}$ \\
\hline \multirow{3}{*}{ Merton Late } & $\mathrm{C}$ & $64.9 \mathrm{a}$ & $10.2 \mathrm{a}$ & $26.9 \mathrm{a}$ & $3.8 \mathrm{a}$ & 2.3 \\
\hline & $\mathrm{CaCl}_{2}$ & $60.1 \mathrm{~b}$ & $9.0 \mathrm{~b}$ & $25.1 \mathrm{~b}$ & $3.7 \mathrm{~b}$ & 2.7 \\
\hline & $P$ & * & $*$ & $*$ & $*$ & $\mathrm{~ns}$ \\
\hline
\end{tabular}

T: Treatments; C: Control; $\mathrm{CaCl}_{2}$ : Calcium chloride; TPC: Total phenolics content (mg GAE $\left.100 \mathrm{~g}^{-1} \mathrm{FW}\right)$; AsA: Ascorbic acid (mg 100 g ${ }^{-1}$ FW); TAC: Total anthocyanin content (mg cy-3-glu kg $\left.{ }^{-1} \mathrm{FW}\right)$; AA: Antioxidant activity ( $\mathrm{mg} \mathrm{TE} \mathrm{g}^{-1} \mathrm{FW}$ ); SCC: Stem chlorophyll content (mg $100 \mathrm{~g}^{-1}$ ); ns: represents nonsignificance at $\mathrm{P}<0.05$; **: Represents significance at the 0.01 level; *: Represents significance at the 0.05 level. Statistical comparisons were made within each cultivar. Means followed by different letters are significantly different $(\mathrm{P}<0.05)$

\subsection{Total phenolics, total anthocyanin and antioxidant activity}

Sweet cherry is an important source of phenolic compounds, which exhibit high antioxidant activity and are essential for human diet (Correia et al. 2017). Phenolic compounds also have important role on some quality characteristics of fruit such as color, taste and aroma (Göksel 2011). In the present study, the TPC and TAC were significantly affected by $\mathrm{CaCl}_{2}$ treatment in all varieties. The preharvest $\mathrm{Ca}$ treatment delayed the accumulation of both TPC and TAC of cherries compared to control during fruit growth period. The TPC of Ca treated fruit were 2.6\% (0900 Ziraat), 4.05\% (Sweetheart) and 8.0\% (Merton Late) lower than those of control samples. Similar trend was also observed for TAC, and the control fruit had $12.4 \%$ (0900 Ziraat), 7.8\% (Sweetheart) and 7.2\% (Merton Late) higher TAC (Table 1). The slowed accumulation of TPC and TAC in treated fruit can be explained by the suppressing effect of $\mathrm{CaCl}_{2}$ on the ripening processes of cherries. This thought is in agreement with of Correia et al. (2017) who reported that phenolic compounds in sweet cherries, concentrated in the skin, increased with ripening together with total anthocyanin. As can be seen in Figure $1, \mathrm{CaCl}_{2}$ significantly reduced the respiration rate, an indicator of ripening processes, of sweet cherries. Metabolic processes, including respiration rate, are closely associated with cell wall integrity and enzyme activity, which can be affected by Ca treatments in fruit. Likewise, Sairam et al. (2011) reported that calcium delays ripening and senescence by strengthening the cell wall structure and affecting enzyme activity, and thus reducing the lipid peroxidation in fruit. On the other hand, the suppressing effect of $\mathrm{Ca}$ on the accumulation of TPC and TAC was also recorded after harvest. For example, Diaz-Mula et al. (2017) reported a slow accumulation in total phenolic and anthocyanin of $\mathrm{Ca}$ treated cherries during the first two weeks of cold storage. Similarly, Vangdal et al. (2008) speculated that a reduction in phenolic compounds could be expected in calcium treated sweet cherries compared to control during cold storage.

In accordance to TPC and TAC, the antioxidant activity of all treated varieties was lower compared to control fruit as expected (Table 1). There is a highly correlated relationship between total antioxidant activity and total phenolics and anthocyanin in fruit (Saracoglu et al. 2017; Koyuncu et al. 2019). The effect of Ca treatment on AA of sweet cherries was significant except for 0900 Ziraat variety. The AA of treated cherries were determined as $3.4,3.2$ and $3.7 \mathrm{mg}^{\mathrm{TE}} \mathrm{g}^{-1} \mathrm{FW}$ in 0900 Ziraat, Sweetheart and Merton Late, respectively, which 3-4 \% lower than those of control fruit (Table 1). As mentioned above, this can be due to the slowing down of ripening and senescence processes by $\mathrm{CaCl} 2$ treatment. Supporting this thought, Serradilla et al. (2012) determined a significant increase in total phenols and antioxidant activity of sweet cherries during ripening.

\section{Conclusions}

Preharvest $\mathrm{CaCl}_{2}$ treatment remarkable reduced respiration rate and SSC and maintained titratable acidity and fruit firmness of sweet cherries compared to control at ripening stage. In all varieties, $\mathrm{CaCl}_{2}$ delayed the accumulation of AsA, SCC, TPC and TAC in comparison to control fruit. Similar to TPC and TAC, the antioxidant activity of fruit was reduced by $\mathrm{CaCl}_{2}$ treatment at harvest. The skin color of treated fruit was more attractive, with higher $\mathrm{h}^{\circ}$ and $\mathrm{L}^{*}$ values, compared to control. The glucose and fructose, the major soluble sugars, and total sugar contents of treated cherries were lower than those of control fruit at harvest. The response level of each variety to preharvest $\mathrm{CaCl}_{2}$ treatment varied; however, the direction of changes was similar for each quality characteristic in all varieties.

\section{References}

Aghdam M S, Dokhanieh A Y, Hassanpour H \& Fard J R (2013). Enhancement of antioxidant capacity of cornelian cherry (Cornus mas) fruit by postharvest calcium treatment. Scientia Horticulturae 161: 160-164. https://doi.org/10.1016/j.scienta.2013.07.006

Ağlar E, Öztürk B, Güler S K, Karakaya O, Uzun S \& Saraçoğlu O (2017). Effect of modified atmosphere packaging and 'Parka' treatments on fruit quality characteristics of sweet cherry fruits (Prunus avium L. 0900 Ziraat) during cold storage and shelf life. Scientia Horticulture 222: 162-168. https://doi.org/10.1016/j.scienta.2017.05.024 
Ballistreri G, Continella A, Gentile A, Amenta M, Fabroni S \& Rapisarda P (2013). Fruit quality and bioactive compounds relevant to human health of sweet cherry (Prunus avium L.) cultivars grown in Italy. Food Chemistry 140(4): 630-638. https://doi.org/10.1016/j.foodchem.2012.11.024

Correia S, Schouten R, Silva A P \& Gonçalves B (2017). Factors affecting quality and health promoting compounds during growth and postharvest life of sweet cherry (Prunus avium L.). Frontiers in Plant Science 8: 2166. https://doi.org/10.3389/fpls.2017.02166

Correia S, Queirós F, Ribeiro C, Vilela A, Aires A, Barros A I, Schouten R, Silva A P \& Gonçalves B (2019). Effects of calcium and growth regulators on sweet cherry (Prunus avium L.) quality and sensory attributes at harvest. Scientia Horticulturae 248: 231-240. https://doi.org/10.1016/j.scienta.2019.01.024

Crisosto CH, Crisosto GM \& Metheney P (2003). Consumer acceptance of 'Brooks' and 'Bing' cherries is mainly dependent on fruit SSC and visual skin color. Postharvest Biology and Technology 28: 159-167. https://doi.org/10.1016/S0925-5214(02)00173-4

Diaz-Mula H M, Valero D, Guillén F, Valverde J M, Zapata P J \& Serrano M (2017). Postharvest treatment with calcium delayed ripening and enhanced bioactive compounds and antioxidant activity of 'Cristalina' sweet cherry. Acta Horticulturae 1161: 511-514. https://doi.org/10.17660/ActaHortic.2017.1161.81

Dong Y, Zhi H \& Wang Y (2019). Cooperative effects of pre-harvest calcium and gibberellic acid on tissue calcium content, quality attributes, and in relation to postharvest disorders of late-maturing sweet cherry. Scientia Horticulturae 246: 123-128. https://doi.org/10.1016/j.scienta.2018.10.067

Erbas D, Koyuncu M A, Özüsoy F \& Onursal C E (2018). Effects of pre-harvest putrescine treatment on fruit quality of sweet cherry cv. 0900 Ziraat. Academic Journal of Agriculture 7(2): 151-156. http://dx.doi.org/10.29278/azd.476202 (In Turkish)

Erogul D (2014). Effect of preharvest calcium treatments on sweet cherry fruit quality. Notulae Botanicae Horti Agrobotanici Cluj-Napoca 42(1): 150-153. https://doi.org/10.15835/nbha4219369

Göksel Z (2011). Effects of some pre-treatments on storability of sweet cherries. PhD Thesis, Ege University, Turkey (Pressed).

Gonçalves B, Silva A P, Moutinho-Pereira J, Bacelar E, Rosa E \& Meyer A S (2007). Effect of ripeness and postharvest storage on the evolution of colour and anthocyanins in cherries (Prunus avium L.). Food Chemistry 103: 976-984. https://doi.org/10.1016/j.foodchem.2006.08.039

Kirkby E A \& Pilbeam D J (1984). Calcium as a plant nutrient. Plant, Cell and Environment 7: 397-405. https://doi.org/10.1111/j.13653040.1984.tb01429.x

Koyuncu M A, Erbaş D, Onursal C E, Seçmen T, Güneyli A \& Üzümcü S S (2019). Postharvest treatments of salicylic acid, oxalic acid and putrescine influences bioactive compounds and quality of pomegranate during controlled atmosphere storage. Journal of Food Science and Technology 56(1): 350-359. https://doi.org/10.1007/s13197-018-3495-1

Lidster P D, Porritt S W \& Tung M A (1978). Texture modification of 'Van' sweet cherries by postharvest calcium treatments. Journal of the American Society for Horticultural Science 103: 527-530

Mahmood M, Anwar F, Abbas M, Boyce M C \& Saari N (2012). Compositional variation in sugars and organic acids at different maturity stages in selected small fruits from Pakistan. International Journal of Molecular Sciences 13: 1380-1392. https://doi.org/10.3390/ijms13021380

Martínez-Romero D, Alburquerque N, Valverde J M, Guillén F, Castillo S, Valero D \& Serrano M (2006). Postharvest sweet cherry quality and safety maintenance by aloe vera treatment: A new edible coating. Postharvest Biology and Technology 39(1): 93-100. https://doi.org/10.1016/j.postharvbio.2005.09.006

Melgarejo P, Salazar D M \& Artes F (2000). Organic acid and sugar composition of harvested pomegranate fruits. European Food Research and Technology 211: 185-190. https://doi.org/10.1007/s002170050021

Michailidis M, Karagiannis E, Tanou G, Karamanoli K, Lazaridou A, Matsi T \& Molassiotis A (2017). Metabolomic and physico-chemical approach unravel dynamic regulation of calcium in sweet cherry fruit physiology. Plant Physiology and Biochemistry 116: 68-79. https://doi.org/10.1016/j.plaphy.2017.05.005

Monsalve-Gonalez A, Barbosa-Cánovas G V \& Cavalieri R P (1993). Mass transfer and textural changes during processing of apples by combined methods. Journal of Food Science 58(5): 1118-1124. https://doi.org/10.1111/j.1365-2621.1993.tb06128.x

Mozetič B, Trebše P, Simičič M \& Hribar J (2004). Changes of anthocyanins and hydroxycinnamic acids affecting the skin colour during maturation of sweet cherry (Prunus avium L.). Lebensmittel-Wissenschaft und -Technologie 37: 123-128. https://doi.org/10.1016/S0023-6438(03)00143-9

Mozetič B, Simčič M \& Trebše P (2006). Anthocyanins and hydroxycinnamic acids of Lambert Compact cherries (Prunus avium L.) after cold storage and 1-methylcyclopropene treatment. Food Chemistry 97(2): 302-309. https://doi.org/10.1016/j.foodchem.2005.04.018

Ozturk B, Aglar E, Karakaya O, Saracoglu O \& Gun S (2019). Effects of preharvest $\mathrm{GA}_{3}, \mathrm{CaCl}_{2}$ and modified atmosphere packaging treatments on specific phenolic compounds of sweet cherry. Turkish Journal of Food and Agriculture Sciences 1(2): 44-56. https://doi.org/10.14744/turkjfas.2019.009

Ranjbar S, Rahemi M \& Ramezanian A (2018.) Comparison of nano-calcium and calcium chloride spray on postharvest quality and cell wall enzymes activity in apple cv. Red Delicious. Scientia Horticulturae 240: 57-64. https://doi.org/10.1016/j.scienta.2018.05.035

Romano G S, Cittadini E D, Pugh B \& Schouten R (2006). Sweet cherry quality in the horticultural production chain. Stewart Postharvest Review 6(2): 1-9. https://doi.org/10.2212/spr.2006.6.2

Saba M K \& Sogvar O B (2016). Combination of carboxymethyl cellulose-based coatings with calcium and ascorbic acid impacts in browning and quality of fresh-cut apples. LWT - Food Science and Technology 66: 165-171. https://doi.org/10.1016/j.lwt.2015.10.022

Saracoglu O, Ozturk B, Yildiz K \& Kucuker E (2017). Pre-harvest methyl jasmonate treatments delayed ripening and improved quality of sweet cherry fruits. Scientia Horticulturae 226: 19-23. https://doi.org/10.1016/j.scienta.2017.08.024

Sairam R K, Vasanthan B \& Arora A (2011). Calcium regulates Gladiolus flower senescence by influencing antioxidative enzymes activity. Acta Physiologiae Plantarum 33: 1897-1904. https://doi.org/10.1007/s11738-011-0734-8

Schick J L \& Toivonen P M (2002). Reflective tarps at harvest reduce stem browning and improve fruit quality of cherries during subsequent storage. Postharvest Biology and Technology 25(1): 117-121. https://doi.org/10.1016/S0925-5214(01)00145-4

Serradilla M J, Martín A, Ruiz-Moyano S, Hernández A M, López-Corrales M \& Córdoba M G (2012). Physicochemical and sensorial characterisation of four sweet cherry cultivars grown in Jerte Valley (Spain). Food Chemistry 133: 1551-1559. https://doi.org/10.1016/j.foodchem.2012.02.048

Serrano M, Guillén F, Martinez-Romero D, Castillo S \& Valero D (2005). Chemical constituents and antioxidant activity of sweet cherry at different ripening stages. Journal of Agricultural and Food Chemistry 53: 2741-2745. https://doi.org/10.1021/jf0479160 
Thaipong K, Boonprakob U, Crosby K, Cisneros-Zevallos L \& Byrne D H (2006). Comparison of ABTS, DPPH, FRAP, and ORAC assays for estimating antioxidant activity from guava fruit extracts. Journal of Food Composition and Analysis 19: 669-675. https://doi.org/10.1016/j.jfca.2006.01.003

Tsantili E, Rouskas D, Christopoulos M V, Stanidis V, Akrivos J \& Papanikolaou D (2007). Effects of two pre-harvest calcium treatments on physiological and quality parameters in 'Vogue' cherries during storage. The Journal of Horticultural Science and Biotechnology 82(4): 657-663. https://doi.org/10.1080/14620316.2007.11512287

Vangdal E, Hovland K L, Børve J, Sekse L \& Slimestad R (2008). Foliar application of calcium reduces postharvest decay in sweet cherry fruit by various mechanisms. Acta Horticulturae 768: 143-148. https://doi.org/10.17660/ActaHortic.2008.768.16

Wang Y, Xie X \& Long L E (2014). The effect of postharvest calcium application in hydro-cooling water on tissue calcium content, biochemical changes, and quality attributes of sweet cherry fruit. Food Chemistry 160: 22-30. https://doi.org/10.1016/j.foodchem.2014.03.073

Watada A E (1982). A high-performance liquid chromatography method for determining ascorbic acid content of fresh fruits and vegetables. HortScience 17(3): 334-335

Winkler A \& Knoche M (2019). Calcium and the physiology of sweet cherries: A review. Scientia Horticulturae 245: 107-115. https://doi.org/10.1016/j.scienta.2018.10.012

Winkler A, Fiedler B \& Knoche M 2020. Calcium physiology of sweet cherry fruits. Trees-Structure and Function 34 (2020): $1157-1167$. https://doi.org/10.1007/s00468-020-01986-9

(C) 2022 by the author(s). Published by Ankara University, Faculty of Agriculture, Ankara, Turkey. This is an Open Access article distributed under the terms and conditions of the Creative Commons Attribution (CC BY) license (http://creativecommons.org/licenses/by/4.0/), which permits unrestricted use, distribution, and reproduction in any medium, provided the original work is properly cited. 